\title{
THE EFFECT OF ONLINE TRAVEL AGENCIES (OTA) ON BRAND RELATIONSHIPS IN LOW AND HIGH-END HOTELS IN SOUTH AFRICA
}

\author{
Abigail CHIVANDI* \\ University of the Witwatersrand, Faculty of Commerce, Law and Management, School of Economic \& Business Sciences, \\ Richard Ward, 1 Jan Smuts Ave, Braamfontein, Johannesburg, 2000, South Africa, e-mail: Abigail.Chivandi@wits.ac.za \\ Olorunjuwon SAMUEL \\ University of the Witwatersrand, Faculty of Commerce, Law and Management, School of Economic \& Business Sciences, \\ Richard Ward, 1 Jan Smuts Ave, Braamfontein, Johannesburg, 2000, South Africa, e-mail: olorunjuwon.samuel@wits.ac.za
}

Mammo MUCHIE

Tshwane University of Technology Pretoria, Faculty of Engineering, Gauteng, South Africa, e-mail: MuchieM@tut.ac.za

Citation: Chivandi, A., Samuel, O., \& Muchie, M. (2020). THE EFFECT OF ONLINE TRAVEL AGENCIES (OTA) ON BRAND RELATIONSHIPS IN LOW AND HIGH-END HOTELS IN SOUTH AFRICA. GeoJournal of Tourism and Geosites, 31(3), 951-957. https://doi.org/10.30892/gtg.31303-526

\begin{abstract}
The purported study explored Online Travel Agencies (OTA) influence on consumers brand relationships towards hotels and provided convenient and easy purchase decisions for South African Millennial consumers who travel or intend to travel. Empirical and theoretical investigation in in low and high-end hotel groups was executed, explored the research problem aimed at filling the gap. Hypotheses were quantitatively tested using Structural Equation Modelling (SEM), Confirmatory Factor Analysis (CFA) tested reliability and validity. A quantitative methodology philosophy was used, and random sampling employed to selected respondents among the millennials and Amos and SPSS 25 obtained CFA and path model to determine best model fit. Findings indicated that there is a positive relationship between hotel brand loyalty and repurchase intentions. However, consumer may be attitudinally loyal and may need marketing incentives to ensure that the consumer become behaviourally loyal to ensure visitation to the hotel brand. Originality and value of the research is in the study proving significant insight into the travel industry and in its ability to provide marketers an understanding of customer satisfaction and retention, fresh contemporary evidence supported by reliable information contributing to body of knowledge giving lieu-way into further research on brand relationships in low \& high-end hotels.
\end{abstract}

Key words: Brand Loyalty, Hotel Groups, -End, Low -End, Relationships, Millennials, Travel Agents.

$* * * * * *$

\section{INTRODUCTION}

The web has changed the travel industry and the conduct of voyagers by giving a wellspring of circulation and correspondence that crossed over any barrier among customers and providers. Preceding the web the lodging business was dependent on movement intermediates, for example, travel operators, to circle promoting material and to guarantee buys were made by buyers. The web permits go providers to achieve clients straightforwardly without depending on middle people (Amaro and Duarte, 2015). With the following 10 years recent college grads (Generation Y) will be a huge client sections for inns around the world, in this manner, it is essential for advertisers to make associations with twenty to thirty year olds (Bilgihan, 2020). Online and portable booking can be finished through a middle person, for example, Online Travel Agencies [OTA] (Yang et al., 2015). OTA's are helpful and simple by giving a variety of exchanges, including flights and inn appointments. Enabling buyers to asses' practical advantages and mental advantages and that may drive brand reliability (Ozturk et al., 2016; Yeh et al., 2016). An online delegates' job, for example, an OTA is to discover providers and potential buyers. Besides, to decide the costs of the item or administration, building up the terms of exchanges, keep record of installments and exchanges just as give arrangements of accessibility of merchandise and ventures (Yang et al., 2015).

Customer value theory states that value perception is the fundamental to brand loyalty as consumers remain loyal if they notice more value from a brand (Yeh et al., 2016). Datta et al (2018) stated that the factors of brand loyalty are functional value, emotional value, and social value as grounded on consumer value theory. However, value can elicit brand loyalty this can be understood in terms of functional value, emotional value and social value (Kherrour et al., 2018). Whereby, functional value creates consumers' preference and loyalty to the brand (Kontsiwe and Visser, 2019). Emotional value when perceived higher, consumers have brand loyalty evidently seen in repurchase intentions, will to pay, and positive word-of-mouth (Munien et al., 2019). Social value when perceived as higher, consumers show greater brand loyalty behaviours of disseminating positive information and accepting premium prices (Yeh et al., 2016). Furthermore, Baiburiev et al (2018) found that value motivates consumers to purchase repeatedly where consumer purchase decisions are made on product evaluations. Whereby perceived value is the customer's valuations on quality and price of products and services post-purchase as well as the advantage gained from the product and brand (Ercis et al., 2012). Pre-purchase information is whether the product or service meets customer's functional needs and is affected by product factors, customer's factors as well as situational factors (Kotler and Keller, 2012; Schiffman and Wisenblit, 2015 in Chivandi, 2018).

\section{LITERATURE REVIEW AND HYPOTHESIS DEVELOPMENT}

IT has grown and has altered the behaviour of travellers (Crnojevac et al., 2010). Online distribution of services such as for hotel is increasing as these online services benefit both the hotels and travellers (Stangl et al., 2016). There is an increase in m-commerce (mobile commerce) as an increasing number of mobile devices that are being used to make payments online (Ozturk et al., 2016). Where Tourism is the top industry in online transactions volume and hotel reservations the second most bought online travel product (Bilgihan 2020; Stangl et al., 2016). Hospitality enterprises are using numerous online distribution channels to foster online purchasing and for visibility in increasing 
awareness and interest (Morgan et al., 2009). Rogerson et al, (2016) found that how those traditional channels (i.e., telephone, fax, letters and walk-ins) still play a dominant role in terms of distributing hotel room; however, OTAs who have a strong position as a booking channel. The OTAs have a global reach that can build on economies of scope and scale, aggregate products, offer deals in multiple languages and provide a convenient shopping for all travel one site. On average hoteliers use 3.61 OTAs Interestingly (Stangl et al., 2016). The Internet has transformed the way of business (Cantallops and Salvi, 2020). Whereby tourists are more demanding, more informed and educated as well as more aware of the diversity of choices available to them (Tuzunkan et al., 2018). Crnojevac et al (2010) found that due to online booking consumers are more sophisticated as online booking have made consumers increasingly powerful and more so able determine the elements of tourist products. The study established that customers of tourism have become increasingly difficult to satisfy (Datta et al., 2018). This change in behaviour has led to the growth of online distribution (Morgan et al., 2009). The key reasons for the internet's advancement as a reservations channel is the internet's dependability as a channel for intangible goods, customers presume items online to be sold are less expensive, the internet's allowance for fast price assessments and reduced search charges and customers can get in direct communication with the seller (Baiburiev et al., 2018). Online Travel Agencies (OTAs) came about in the 1990's. OTAs are third-party companies that sell products from multiple suppliers. OTAs place a disadvantage on hotels by compelling hotels to sell a great number of their inventory using intermediaries, sold frequently at discounted prices Cohen and Crabtree, 2006). OTAs create economies of scope, gather products and reduce costs for cost effective solutions in providing deals that are superior to the deals on hotels own websites (Rogerson et al., 2019). OTAs use data mining to adapt direct mail and loyalty programmes. There are many difficulties for hoteliers as OTAs can generate customer value and provide ease in information search and booking (Ferketich, 2015). Hoteliers are losing control over their products and brands because of their reliance on OTAs (Kherrour et al., 2018). OTAs hinder a hotel from nurturing a relationship with a customer by making price, location, photos and reviews as of greater significance than the hotel brand for potential guests.

The online price transparency of OTAs has caused price competition and reduced guest loyalty. However, Independent hotels are more so dependent on an OTA for brand awareness to attract guests (Logt, 2017). Thus, it is important that hoteliers assess their relationships in distribution networks to ensure that they get exposure to the market and exploit the share of the total value obtained from being part of a network (Datta et al., 2018). The booking process varied according to the type of travel, where guests did not book on the internet for a business trip or group tour. Whereas guests booked on the internet when staying for a conference or for holiday (Caruana, 2020).Generational cohorts share life experiences which cause them to develop similar attitudes and beliefs. Shared life experiences and social context trigger each generational cohort to develop different beliefs, expectations and views regarding their lives and consequently different behaviours which results in cohorts developing their own distinct characteristics (Bilgihan, 2020).

Marketers need to create relationships between their brands and the Generation Y consumers through various steps to increase brand loyalty of this disloyal segment (Ushakov et al., 2019). This cohort process websites faster than older generations and they are moving away from standard text toward images, compelling videos and social websites. Therefore, hotel marketers should understand their responses to online marketing efforts and design their websites accordingly to drive online bookings (Bilgihan, 2020). Websites can create a positive tie between the traveller and the hotel brand. It is fundamental for hotels to have websites that appeal customers and reassure online booking to establish customer loyalty (Tuzankan, 2018). Millennials are interested in travel as well as experiences and will be the most significant customer base for hotels. People under age 30 travel 4.7 times per year on business compared to 3.6 times per year for 30 to 45 - year-olds. (Morgan, 2009). Chuah et al., (2017) study found that Gen Y consumers are price conscious yet have emotional value as greater importance. The difference is the generations, the study suggests may be a result of Generation Y having been brought up in a world of changes regarding experiences, technologies, and cultural and environmental changes. Making Generation Y's needs and expectations may different causing changes in satisfaction and loyalty decisions. The study of Rogerson et al (2019), furthermore stated the need for customer-centric (relational and customization) value to satisfying and retaining this cohort. Whereby this generation are motivated by incentives and they want their loyalty to be reciprocated. Consumer decision making process is when consumers search and evaluate the information and make a decision.

A model of customer basic leadership takes a gander at a buyers' methodology in choosing an item among the contenders just as presentations the stages shoppers experience when settling on a buy choice just as post buy conduct (Dudovskiy, 2013). As indicated by (Schiffman and Wisenblit, 2015) the items and administrations the buyer are settling on are required to fulfill their necessi ties. The Fornell and Larcker, 1981) model of customer basic leadership process incorporates three segments, info, procedure and yield. The model is utilized to make and facilitate significant ideas into an entire. As indicated by Yeh et al., (2016) this procedure stage is noteworthy to the investigation in deciding why twenty to thirty year olds settle on buy choices. The pre-data seek inside the investigation can be controlled by taking a gander at the useful, reasonable and enthusiastic requirements of the shopper (the client's qualities). Schiffman and Wisenblit (2015) states that post buy assessment is significant in the investigation repurchase is an aftereffect of a client's decisions and sentiments. Repurchase is noteworthy as the expectation for a shopper to repurchase means that the customer's image reliability and trust to the brand. Anticipation Disconfirmation Theory (EDT) - The hope disconfirmation takes a gander at the connection among disconfirmation and fulfillment (Datta et al., 2018). The investigation found that lament has a circuitous effect on reuse aim through fulfillment and lament impacts the degree to which clients are disappointed and fulfillment impacts the aim to reuse. Liao et al., (2020) recommends that administration quality may diminish lament therefore essentially improve online consumer loyalty. Liao et al., (2020) saw a positive connection between site characteristics to fulfillment, anyway was a negative relationship to lament. This investigation of (Dudovskiy, 2013) proposes estimating lament with EDP, as lament contrarily influences fulfillment and reuse aim. Elements that impact client faithfulness can be comprehended as inside and outside variables. Inside variables incorporate the item itself, administration quality, advancement blend, and expenses (Yoo and Baib, 2013). Outside components are including exchanging costs, situational factors, saw esteem, fulfillment, duty, and trust (Yoo and Baib, 2020). It is apparent from the talk underneath that in the friendliness/lodging industry division, brand loyality impacts on authoritative notoriety, client esteem and repu rchase goal. Accordingly in embraced this examination we conjectured that there is a huge connections on the exploration builds.

\section{MATERIALS AND METHODS}

This examination made utilization of a quantitative research system that by and large included the gathe ring of essential information from an objective populace of those dwelling in Gauteng South Africa and are over the age of 18. This was improved the situation the reason for catching the more extensive populace of age y associate/millennial. Quantitative essential research was directed utilizing a self-managed poll to gather information. The poll configuration permitted the assurance of the Confirmatory Factor Analysis files, ChiSquare/level of opportunity, Comparative Fit Analysis and the Incremental Index of Fit. A cross-sectional examination was directed because of time impediments which limited the utilization of longitudinal investigations. The populace alludes to the all out gathering and additionally components important to the analyst whom the specialist embarks to question so as to get data and making educated 
derivations (Likert, 2016). In this investigation the example outline are people in CBD-Braamfontein Johannesburg who are trying to travel or who are dynamic explorers, who possess a keen versatile devise or claim a PC to direct on the web and portable appointments through an OTA and have an emphasis on the millennial populace (age y).

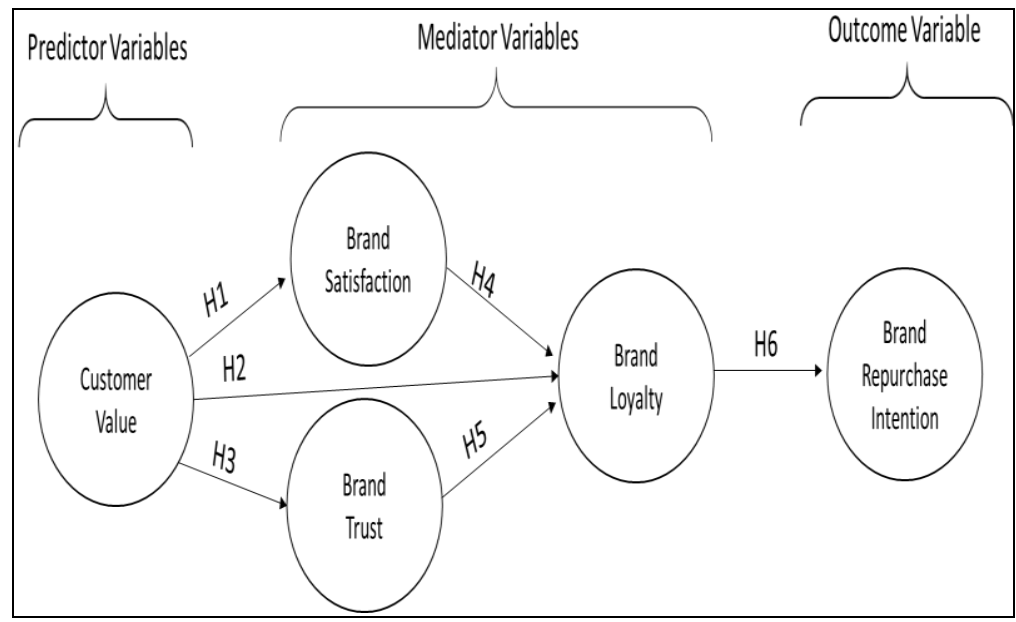

Figure 1. Conceptual Model (Source: Chivandi et al., 2019)

H1: Customer Value has a positive relationship on customer brand satisfaction

H2: Customer Value has a positive relationship on brand loyalty

$H_{3}$ : Customer Value has a positive relationship on customer brand trust

$H_{4}$ : Brand satisfaction has a positive relationship on brand Loyalty.

$H_{5}:$ Brand trust has a positive relationship on brand loyalty

$H_{6}$ : Brand loyalty has positive relationship on brand repurchase Intention

\section{RESULTS DISCUSSIONS}

\section{Sample Description}

Table 1. Summary of demographics (Data source: Chivandi et al., 2019)

\begin{tabular}{|c|c|c|}
\hline Age & Frequency & Percent $(\%)$ \\
\hline $18-22$ & 195 & 78.0 \\
\hline $23-27$ & 35 & 14.0 \\
\hline $28-32$ & 3 & 1.2 \\
\hline Above32 & 17 & 6.8 \\
\hline Total & 250 & 100.0 \\
\hline Gender & Frequency & Percent $(\%)$ \\
\hline Male & 71 & 28.4 \\
\hline Female & 175 & 70.0 \\
\hline Prefer not to say & 4 & 1.6 \\
\hline Total & 250 & 100.0 \\
\hline Do you own a smart device (e.g. mobile phone, tablet) or laptop/computer & Frequency & Percent $(\%)$ \\
\hline Yes & 247 & 98.8 \\
\hline No & 3 & 1.2 \\
\hline Total & 250 & 100.0 \\
\hline Have you booked accommodation at a hotel? & Frequency & Percent $(\%)$ \\
\hline Never & 29 & 11.6 \\
\hline I intend to in the future & 67 & 26.8 \\
\hline Yes & 154 & 61.6 \\
\hline Total & 250 & 100.0 \\
\hline $\begin{array}{l}\text { Have you used an hotel online travel agency (such as Trivago, Hotels.com and } \\
\text { booking.com) to make hotel booking decisions? }\end{array}$ & Frequency & Percent (\%) \\
\hline Always & 45 & 18.0 \\
\hline Sometimes & 101 & 40.4 \\
\hline Never & 104 & 41.6 \\
\hline Total & 250 & 100.0 \\
\hline Do you use Air BnB when searching for travel accommodation? & Frequency & Percent $(\%)$ \\
\hline I don't use Air BnB & 153 & 61.2 \\
\hline I sometimes use Air BnB & 81 & 32.4 \\
\hline I always use Air BnB & 16 & 6.4 \\
\hline Total & 250 & 100.0 \\
\hline If you have booked through a hotel, in your last hotel booking what was the star rating? & Frequency & Percent $(\%)$ \\
\hline One $*$ & 4 & 1.6 \\
\hline Two ** & 6 & 2.4 \\
\hline Three $* * *$ & 63 & 25.2 \\
\hline Four $* * * *$ & 115 & 46.0 \\
\hline Five $* * * * *$ & 62 & 24.8 \\
\hline Total & 250 & 100.0 \\
\hline
\end{tabular}


The demographic profile is given of the respondents of age and gender. Followed by the questions on whether the respondents have a smart device (e.g. mobile phone, tablet) or laptop/computer, have booked accommodation at a hotel, have used an hotel online travel agency (such as Trivago, Hotels.com and booking.com) to make hotel booking decisions, have used Air BnB when searching for travel accommodation and whether the respondents last hotel booking was a star rating of either one star or to five stars.

Thereafter the average mean standard deviation of each research construct is given (Table 1).

The respondents, $78 \%$ are between the age ranges of 18-22 with 70\% being female. Most of the respondents own a smart devise or laptop/computer at $98.8 \%$. Regarding booking of hotels, $61.6 \%$ have booked hotel accommodation before with $58.4 \%$ having at some stage booked accommodation through an online travel agency. Air BnB however is not a prominent accommodation service with only $6.4 \%$ of respondents stating that they always use Air BnB to book hotels. It is evident that most respondents of $70.8 \%$ book high end hotels of either 4 or 5 -star ratings.

Table 2. Summary of descriptive statistics

\begin{tabular}{|c|c|c|c|c|c|c|c|c|}
\hline \multirow{2}{*}{$\begin{array}{l}\text { Research } \\
\text { constructs }\end{array}$} & Scale Item & Cronbach test & Factor Loadings & AVE & $\mathrm{CR}$ & & & \\
\hline & Mean & Std. Deviation & Corrected Item-Total Correlation & $\alpha$ value & & & & \\
\hline \multirow{4}{*}{$\mathrm{CV}$} & CV 1 & 3.86 & 0.830 & 0.468 & \multirow{4}{*}{0.745} & 0.653 & \multirow{4}{*}{0.42} & \multirow{4}{*}{0.74} \\
\hline & CV 2 & 3.63 & 0.990 & 0.414 & & 0.625 & & \\
\hline & CV 3 & 3.74 & 1.042 & 0.410 & & 0.605 & & \\
\hline & $\mathrm{CV} 4$ & 4.01 & 0.845 & 0.540 & & 0.706 & & \\
\hline \multirow{4}{*}{ SAT } & SAT 1 & 4.13 & 0.852 & 0.664 & \multirow{4}{*}{0.930} & 0.871 & \multirow{4}{*}{0.77} & \multirow{4}{*}{0.93} \\
\hline & SAT 2 & 4.15 & 0.840 & 0.709 & & 0.913 & & \\
\hline & SAT 3 & 4.12 & 0.858 & 0.654 & & 0.878 & & \\
\hline & SAT 4 & 4.02 & 0.869 & 0.719 & & 0.852 & & \\
\hline \multirow{4}{*}{ TR } & TR 1 & 4.03 & 0.929 & 0.681 & \multirow{4}{*}{0.842} & 0.805 & \multirow{4}{*}{0.59} & \multirow{4}{*}{0.85} \\
\hline & TR 2 & 3.46 & 1.216 & 0.635 & & 0.707 & & \\
\hline & TR 3 & 3.86 & 0.951 & 0.682 & & 0.815 & & \\
\hline & TR 4 & 4.11 & 0.864 & 0.636 & & 0.749 & & \\
\hline \multirow{5}{*}{ LO } & LO 1 & 4.12 & 0.908 & 0.765 & \multirow{5}{*}{0.913} & 0.845 & \multirow{5}{*}{0.69} & \multirow{5}{*}{0.92} \\
\hline & LO 2 & 4.13 & 0.918 & 0.767 & & 0.877 & & \\
\hline & LO 3 & 3.92 & 1.059 & 0.768 & & 0.874 & & \\
\hline & LO 4 & 3.60 & 1.068 & 0.700 & & 0.729 & & \\
\hline & LO 5 & 3.80 & 1.053 & 0.744 & & 0.808 & & \\
\hline \multirow{4}{*}{ INT } & INT 1 & 3.02 & 1.225 & 0.568 & \multirow{4}{*}{0.888} & 0.840 & \multirow{4}{*}{0.67} & \multirow{4}{*}{0.89} \\
\hline & INT 2 & 2.96 & 1.228 & 0.500 & & 0.854 & & \\
\hline & INT 3 & 2.87 & 1.220 & 0.445 & & 0.858 & & \\
\hline & INT 4 & 3.00 & 1.242 & 0.509 & & 0.715 & & \\
\hline
\end{tabular}

The standard deviation is the data values average distance from the mean (average), thus indicating how far-off a value is from the mean. A low standard deviation indicates that the results are near the mean (Plooy-Cilliers et al., 2014). Indicates for customer value that the respondents agreed to the statements measuring the construct with overall mean of $(M=3.6)$, Indicates for brand satisfaction that the respondents agreed to the statements measuring the construct with overall mean of $(M=4)$, Indicates for brand trust that the respondents agreed to the statements measuring the construct with overall mean of $(\mathrm{M}=3.8)$, Indicates for brand loyalty that the respondents agreed to the statements measuring the construct with overall mean of $(M=3.9)$ and Indicates for customer value that the respondents where neutral to the statements measuring the construct with overall mean of $(M=3)$ The Cronbach's Alpha Coefficient is the average of all split-half coefficients resulting from different ways of splitting the scale items. The coefficient assesses the consistency of the entire scale (Hair et al., 2010). This coefficient varies from 0 to 1 , and a value of 0.6 or less generally indicates unsatisfactory internal consistency reliability (Malhotra and Birks, 2006). The agreed upon lower limit of the Cronbach Alpha is 0.70 (Hair et al., 2010). An important property of coefficient alpha is that its value tends to increase with an increase in the number of scale items (Malhotra and Birks, 2006). Thus, will increase the reliability value (Hair et al., 2010). The $\alpha$ Values are greater than 0.6 for each research construct, all values are between 0.745 and $0.90 . \alpha$ Value $>0.7$, Customer value $.745>0.7$, Brand satisfaction $.930>0.7$, brand trust $.842>0.7$, brand loyalty $.913>0.7$, brand reuse intention $.888>0.7$. The reliability is confirmed for the measurement instrument 's variables. Average Value Extracted (AVE): The AVE values are larger than 0.4 for each research construct, values are between 0.42 and 0.77 . All items surpassed the 0.4 benchmark thus there are acceptable levels of scale reliability.

Table 3. The correlation matrix for the study is illustrated below

\begin{tabular}{|c|c|c|c|c|c|c|}
\cline { 2 - 7 } & & CV & SAT & TR & LO & INT \\
\hline CV & Pearson Correlation & 1 & & & & \\
\hline SAT & Pearson Correlation & $.507^{* *}$ & 1 & & & \\
\hline TR & Pearson Correlation & $.466^{* *}$ & $.633^{* *}$ & 1 & & \\
\hline LO & Pearson Correlation & $.528^{* *}$ & $.725^{* *}$ & $.751^{* *}$ & 1 & \\
\hline INT & Pearson Correlation & $.247^{* *}$ & $.271^{* *}$ & $.418^{* *}$ & $.449^{* *}$ & 1 \\
\hline
\end{tabular}

**Correlation is significant at the 0.01 level

$\mathrm{NB}$ : Customer value $=\mathrm{CV}$, Brand satisfaction $=\mathrm{SAT}$. Brand trust $=\mathrm{TR}$, Brand loyalty $=\mathrm{LO}$, Brand reuse intention $=\mathrm{INT}$

The constructs identify if the correlations of the latent constructs are less than 1.0, where a value less than 0.7 is recommended and confirms existence of discriminant validity. A value less than 1 is acceptable. Table 2 shows that all the values are less than 1 , thus showing discriminant validity.

Table 4. Model Fit Indices

\begin{tabular}{|c|c|c|c|c|c|c|c|c|}
\hline $\begin{array}{l}\text { Model fit } \\
\text { Criteria }\end{array}$ & $\begin{array}{c}\text { Chi-Square Index } \\
\text { CMIN /DF }\end{array}$ & $\begin{array}{l}\text { Norm Fit } \\
\text { Index NFI }\end{array}$ & $\begin{array}{c}\text { Relative Fit } \\
\text { Index RFI }\end{array}$ & $\begin{array}{l}\text { Incremental } \\
\text { Fit Index IFI }\end{array}$ & $\begin{array}{l}\text { Tucker-Lewis } \\
\text { Index TLI }\end{array}$ & $\begin{array}{l}\text { Comparative } \\
\text { Fit Index CFI }\end{array}$ & $\begin{array}{l}\text { Goodness of } \\
\text { Fit Index GFI }\end{array}$ & $\begin{array}{l}\text { Root Mean Square Error of } \\
\text { Approximation RMSEA }\end{array}$ \\
\hline & 1.783 & .923 & .904 & .965 & .955 & .964 & .905 & .056 \\
\hline
\end{tabular}

The Chi-Square (1.783) is than the threshold of $<2$, thus confirming that there is acceptable fit. The results (NFI of 0.923, RFI of 0.904, IFI of 0.965 , TLI of 0.955 , CFI of 0.964 and GFI of 0.905$)$ confirm the good fit, where the threshold of (>0.9) has been met. Furthermore, RMSEA (0.56) indicates that there is a good fit, by meeting the threshold of $<0.05$. Chi-square Index. 
Table 5. Model fit assessment for path model

\begin{tabular}{|c|c|c|c|c|c|c|c|c|}
\hline $\begin{array}{l}\text { Model fit } \\
\text { Criteria }\end{array}$ & $\begin{array}{c}\text { Chi-Square Index } \\
\text { CMIN /DF }\end{array}$ & $\begin{array}{l}\text { Norm Fit } \\
\text { Index NFI }\end{array}$ & $\begin{array}{c}\text { Relative Fit } \\
\text { Index RFI }\end{array}$ & $\begin{array}{l}\text { Incremental } \\
\text { Fit Index IFI }\end{array}$ & $\begin{array}{l}\text { Tucker-Lewis } \\
\text { Index TLI }\end{array}$ & $\begin{array}{l}\text { Comparative } \\
\text { Fit Index CFI }\end{array}$ & $\begin{array}{l}\text { Goodness of } \\
\text { Fit Index GFI }\end{array}$ & $\begin{array}{l}\text { Root Mean Square Error of } \\
\text { Approximation RMSEA }\end{array}$ \\
\hline & 1.517 & .937 & .918 & .978 & .971 & .977 & .921 & .046 \\
\hline
\end{tabular}

The Chi-Square (1.517) is less the threshold of $<2$, thus confirming that there is acceptable fit. The results (NFI of .937, RFI of 0.918, IFI of 0.978 , TLI of 0.971 , CFI of 0.977 and GFI of 0.921$)$ confirm the good fit, where the threshold of $(>0.9)$ has been met. Furthermore, RMSEA (0.46) indicates that there is a good fit, by meeting the threshold $(<0.05)$ (Yüksel and Yüksel, 2001).

\section{Hypothesis Testing}

The hypotheses and the path coefficients will be discussed in the following section. The path coefficients indicate the strength of the relationship between variables whereby a strong relationship between the two variables is evident in a high $\mathrm{p}$ value. Thus, to establish whether a hypothesis is supported, the $\mathrm{p}$ values are looked at. The hypotheses coefficients of the research study are in the range of $\mathrm{p}<0.01$ to $\mathrm{p}<0.06$; thus, the hypothesis of the study are supported and significant (Schumacker and Lomax, 2004).

Table 6. Results of Structural Equation Model Analysis and hypothesis

\begin{tabular}{|l|c|c|c|l|}
\hline Proposed hypothesis relationships & Hypothesis & Path Coefficients & P-Values & \multicolumn{1}{|c|}{ Rejected/supported } \\
\hline CV SAT & H1 & .665 & $* * *$ & Supported and significant \\
\hline CV LO & H2 & .192 & 0.006 & Supported and moderate significance \\
\hline CV & H3 & .606 & $* * *$ & Supported and significant \\
\hline SAT LO & H4 & .394 & $* * *$ & Supported and significant \\
\hline TR LO & H5 & .419 & $* * *$ & Supported and significant \\
\hline LO & H6 & .418 & $* * *$ & Supported and significant \\
\hline
\end{tabular}

The strongest relationship is identified as hypothesis one that tested the relationship between customer value and brand satisfaction. Thus, indicating a strong relationship between the two variables. the second strongest relationship is hypothesis three (that measured the relationship between customer value and brand trust). However the other hypothesis that had supported and significant relationships are hypothesis four ( that measured the relationship between brand satisfaction and brand loyalty), hypothesis five ( that measured the relationship between brand trust and brand loyalty) and hypothesis six ( that measured the relationship between brand loyalty and brand reuse intention), However the high $p$ value of 0.006 with the low $\beta$ Coefficient of 0.192 indicates that hypothesis 2 (customer value and brand loyalty) still has a significant relationship yet has moderate significance.

\section{$\mathrm{H}_{1}$ : Customer Value has a positive relationship on customer brand satisfaction}

H1: In support of the literature, the study findings were that the value offered by a hotel has a significant on the customer's hotel brand satisfaction. The study found that majority of the respondents agreed to having received value at their last hotel visit, whereby they believed they received a good deal that was highly reasonable as well as extremely good value and worthwhile and were satisfied, pleased, content and delighted about their overall experience of the hotel. The findings of the study are aligned with the findings of Kumar and Advani (2005), Nam et al (2011) and Shafiee and Bazargan (2018). Kumar and Advani (2005) found that the functional benefits of a product are essential for consumers to be satisfied with the brand. Nam et al (2011) confimred that consumers' satisfaction with hotel or restaurant brands is reliant on functional as well as symbolic benefits and Shafiee and Bazargan (2018) found that regarding online shopping that eservice quality is a factor in generating customer satisfaction. The study suggests that hotels should meet and exceed that value offered to hotel guest to establish customer satisfaction. It is important for companies and brands need to meet the standards of quality, service, cleanliness and value; as customer satisfactions are a customer' perceptions of the product to their expectations.

\section{$\mathrm{H}_{2}$ : Customer Value has a positive relationship on brand loyalty}

H2: The finding of the study revealed that Customer value has a positive relationship with brand loyalty. Value stimulates hotel brand loyalty as they feel they have received value, whereby customers would be more inclined to be brand loyal to a hotel if they felt they had received value from the hotel brand.

The findings revealed that the respondents would be brand loyal as they would say positive things about the hotel and recommend the hotel to other people as well as consider revisiting the hotel and encouraging others to visit the hotel. Evidently, the customers of the hotels are more inclined to repeat a purchase when there is value offered. This is supported by the significant and positive relationship between the customer value offered and the brand loyalty and whereby the functional value, emotional value and social value of the hotel increase repurchase intentions of the customer (the outcome of brand loyalty) To offer more value to retain and stimulate loyalty customers it may be important for hotels to offer value added services such as loyalty programs that may collaborate with entities such as airlines and restaurants to establish additional value for the guests.

\section{$\mathrm{H}_{3}$ : Customer Value has a positive relationship on customer brand trust}

H3: The finding revealed that the value received from a hotel that met the expectations of the customer, ensured trust in the hotel brand. Showing a significant relationship between customer value and brand trust and is supported by literature on value and brand trust. So et al (2013) found that and excellent overall assessment of the utility (perceived value), showed greater brand trust and whereby this positive hotel brand evaluation turn into customers' loyalty. The study recommendations that in order remain authentic the brand communication needs to convey functional benefits as well as emotional and social benefits. (Kumar and Advani, 2005).

\section{$\mathrm{H}_{4}$ : Brand satisfaction has a positive influence on brand Loyalty}

H4: The findings revealed that a positive relationship between the variables of brand satisfaction and brand loyalty. Thus, hotel satisfaction has a significant impact on hotel brand loyalty. The study supported by the literature that determined satisfaction as a precursor to brand loyalty. Mostert and Weideman (2016) found that loyalty cannot occur without customer satisfaction wherby there is a positive relationship amid customer satisfaction and behavioural and attitudinal brand loyalty with relationship intention among Generation Y. Nam 
et al., (2011) also agrees to the positive relationship between satisfaction and loyalty and satisfaction is an indicator of future loyalty and business performance (Nam et al., 2011). Regarding the findings of Chuah et al (2017), the study suggests that to improve satisfaction, a base needs to be created for satisfied customers who stay loyal and spread favourable word-of-mouth about a company's services. Generation Y consumers' satisfaction is what leads to their loyalty and when their expectations are not met, this generation may change to a competitor (Mostert and Weideman, 2016). Thus, regarding the findings of Mostert and Weideman (2016) the study recommends understanding of Generation Y's needs and offer products and services to not only meet and exceed their needs.

H5: The findings revealed that there was a postie relationship between brand trust and brand loyalty as trust establishes an important bond between brand and customers, it is one of the determinants of brand loyalty (Ercis et al., 2012). The findings is supported by the literature on the relationship. Tuzunkan (2018) argued that trust has an important effect in the creation of consumer loyalty furthermore a study conducted. Kumar and Advani (2005) stated that consumers' loyalty will be sustained through brand trust where trust may be dependent the conveying of functional benefits (Kumar and Advani, 2005). High trust in a brand will help customers to lessen perceived risk and enable in repeat purchase of the brand. Thus, these customers will make repeat purchases as these customers' will be branding loyal (Kumar and Advani, 2005). For instance, Bilgihan (2020) eluded that the flow of the website during online shopping can develop a customer trust to a website.

\section{$H_{6}:$ Brand loyalty has a positive impact on brand repurchase Intention}

H6: Findings show that there is a positive and significant relationship between brand loyalty and reuse intentions. However, according to the mean value of respondents, respondents were mostly neutral to revising a hotel or recommending the hotel to others. The study suggests that consumers may be affectively brand loyal to a hotel however; consumers do not feel compelled to make a repeat purchase. Suggesting that behaviourally, consumers are not loyal to a hotel brand, yet they are affectively seen as loyal. Those who felt loyal did not feel compelled to use the same hotel, recommend the hotel to others and many have not repeated the hotel purchase and would look for alternative hotels on a travel agency. However, in the future the respondents, marginally, do plan to book the same hotel in the future and not look. However, regarding the revisiting intentions of hotel customers, it is important to understand that the tourism industry there are fewer opportunities for repeat bookings compared to other consumer goods and services. The findings of the study are supported by Dioko et al (2013) who agreed that hotel guests that are attitudinally loyal to a hotel brand are not resistant in switching across hotel brands that have been communicated to them. Furthermore, hotel guests may be unable or unwilling to switch hotel brands as they are constrained by factors thus keeping them in a state of stasis. Therefore, it is imperative not to see a consumer lack of switching (stasis) as loyalty. However, (Dioko et al., 2013 stated that it is important for the guest switching behavior among hotel categories to be undetood by managers, as it gives an indicaton on the hotels brand performance and marketing results.

Hypothetically, this study contributes to literature on consumer behaviour, customer value, brand satisfaction, customer trust, brand loyalty and brand reuse intentions and study contributes academically by confirming the relationships of variables in the research conceptual model. This indicates that the elements of customer vale, brand satisfaction, customer trust are precursor of brand loyalty that can be determined through brand reuse intentions. the research findings of the study provide valuable practical implications for marketers to develop better customer retention strategies for the Generation Y. the findings also provides a contribution to the marketing environment on hotelier's behaviours by determining that most persons that book accommodation at hotels use OTAs with many respondents using Air BnB. Thus, allowing marketers to understand the consumer behaviour of the consumer and competition to the hotel segment. Thus, allowing marketers to understand the consumer behaviour of the consumer and competition to the hotel segment.

\section{CONCLUSION}

In a nutshell, the study findings indicated that consumers are attitudinally and loyal, thus marketers can act on this attitudinal loyalty through establishing brand loyalty programs, discounts, incentives as well as added value in order to get the consumer to revisit the hotel, thus establish behavioural loyalty and with technological advancement engagement of millennials and nurturing their loyalty is a top research priority for marketers to win their business and heart. Limitations the study does not come without its limitations and the limitations for the study are the exclusion of the greater Johannesburg region, in which further research can be examined regarding the variables of brand loyalty that where analysed and determined. In further studies Brand identification, service quality and other precursor of brand loyalty that were excluded from the study can be analysed also be include. Future research The future research can look at the greater Johannesburg region as a sample and furthermore, the study can be conducted within hotel groups and various hotel boutiques to capture the direct target market.

\section{Aknowlegments}

The authors acknowledge to anonymous reviewer/s for their thoughtful suggestions and comments and everybody who contributed to the success of this paper.

\section{REFERENCES}

Amaro, S., \& Duarte, P. (2015). An integrative model of consumers' intentions to purchase travel online. Tourism Management, 46, 64-79. https://doi.org/10.1016/j.tourman.2014.06.006

Bilgihan, A. (2020). Gen Y customer loyalty in online shopping: An integrated model of trust, user experience and branding. Computers in Human Behavior, 61, 103-113. https://doi.org/10.1016/j.chb.2016.03.014

Cantallops, A.S., \& Salvi, F. (2020). New consumer behavior: A review of research on eWOM and hotels. International Journal of Hospitality Management, 26, 41-51. https://doi.org/10.1016/j.ijhm.2013.08.007

Baiburiev, R., David, L., Abdreyeva, S., Zhakupova, A., \& Artemyev A. (2018). Impacts of Tourism Activities on Economy of Kazakhstan. Geojournal of Tourism and Geosites, 22(2), 480-488. https://doi.org/10.30892/gtg.22217-304

Caruana, A. (2020). Service Loyalty: The Effects of Service Quality and the Mediating Role of Customer Satisfaction. European Journal of Marketing, 26(7/8), 811-828. https://doi.org/10.1108/03090560210430818

Chuah, S.H.W., Marimuthu, M., Kandampully, J., \& Bilgihan, A. (2017). What drives Gen Y loyalty? Understanding the mediated moderating roles of switching costs and alternative attractiveness in the value-satisfaction loyalty chain. Journal of Retailing and Consumer Services, 36, 124-136.

Chivandi, A., Muchie, M., \& Samuel, O. ( 2019). Expectance models and work related service innovation and service quality orientation as a business strategic tool in the toursim. Sena Sabah Ed. Tourism Perspectives and Practices. https://doi.org/10.5772/IntechOpen, 82442

Cohen, D., \& Crabtree, B. (2006). Qualitative Research Guidelines Project. [Online] Available at: http://www.qualres.org/HomeCrit-3517.html [Accessed 20 03 2018].

Crnojevac, I.H., Gugić, J., \& Karlovčan, S. (2010). Tourism: A comparison of Online and Offline Bookings and the Importance of Hotel Attributes. JIOS, 34(1), 41-54. 
Dioko, L.A., So, S.I., \& Harrill, R. (2013). Hotel category switching behavior - Evidence of mobility, stasis or loyalty. International Journal of Hospitality Management, 34, 234-244.

Dudovskiy, J. (2013). Consumer Decision Making Process: a detailed analysis. Available at: https://research-methodology.net/consumer-decision-makingprocess-a-detailed-analysis/, Accessed 06.05.2018.

Ercis, A., Unal, S., Candan, F., \& Yildirim, H. (2012). The effect of brand satisfaction, trust and brand commitment on. Social and Behavioral Sciences, 58, 1395-1404. https://doi.org/10.1016/j.sbspro.2012.09.112

Ferketich, D.S. (2015). Focus on psychometrics: Aspects of item analysis. Research in Nursing \& Health, 14(2), 165-168. https://doi.org/10.1002/nur.4770140211

Fornell, C., \& Larcker, D.F. (1981). Evaluating Structural Equation Models with Unobservable Variables and Measurement Error. Journal of Marketing Research, 14(1), 39-50. https://doi.org/10.2307/3151312

Datta, B., Sajnani, M., \& Thomas, J. (2018). The decision making of business travellers in selecting online travel portals for travel booking: an empirical study of delhi national capital region, India. GeoJournal of Tourism and Geosites. 22(2), 339-346. https://doi.org/10.30892/gtg.22205-292

Hair, J.F., Black, W.C., \& Anderson, B.J.B.R.E. (2010). Multivariate Data Analysis. 7 ed. Upper Saddle River, NJ: Pearson Prentice Hall.Education, T. D. (n.d.).

Kherrour, L., Rezzaz, M.A., \& Hattab, S. (2018). Rehabilitation of Geographical Areas for A Tourist Development the Case of Batna Region's Mountains (Algeria). Geojournal of Tourism and Geosites, 22(2), 455-469. https://doi.org/10.30892/gtg.22215-302

Kontsiwe N., \& Visser G. (2019). Tourism as a vehicle for local economic development in small towns? when things go wrong: the case of aliwal north, south africa. GeoJournal of Tourism and Geosites, 27(4), 1334-1346. https://doi.org/10.30892/gtg.27418-437

Kotler, P., \& Keller, K.L. (2012). Marketing Managment. 14 ed. London, Pearson Education.

Kumar, S. R., \& Advani, J. Y. (2005). Factors Affecting Brand Loyalty: A study in an emerging market on fast moving consumer goods. Journal of Customer Behaviour, 4, 251-275.

Morgan, M., Elbe, J., \& de Esteban, Curiel, J. (2009). Has the experience economy Arrived? The views of destination managers in three visitor-dependent areas. International Journal of Tourism Research, 11, 201-216.

Munien, S., Gumede, A., Gounden, R., Bob U., Gounden, D., \& Perry, N.S. (2019). Profile of visitors to coastal and marine tourism locations in cape town, south africa. GeoJournal of Tourism and Geosites, 27(4), 1134-1147. https://doi.org/10.30892/gtg.27402-421

Liao, C. (2020). Applying the Expectancy Disconfirmation and Regret Theories to Online Consumer Behavior. Cyberpsychology, Behaviour, and Social networking, 14(4), 241-246.

Gunn, C. (1972). Vacationscape. Destination tourist regions. Washington DC.

Likert, R. (2016). Atechnique for the measurement of attitudes. Archives of psychology, 22(140), 5-55.

Logt, J.V.D. (2017). The Impact of Online Travel Agencies, Helsinki Haaga-Helia. University of Applied Science.

Malhotra, N.K., \& Birks, D.F. (2006). Marketing Research. 3rd ed. Essex: Prentice Hall, Inc., a Pearson Education Company.

Rogerson, C.M., \& Collins, K.J.E. (2019). Entrepreneurs in craft beer and tourism: perspectives from south africa. GeoJournal of Tourism and Geosites, 27(4), 1158-1172. https://doi.org/10.30892/gtg.27404-423

Mostert, P., \& Weideman, D.P.A.A. (2016). The interrelationships between customer satisfaction, brand loyalty and relationship intentions of Generation Y consumers towards smart phone brands. South Afican Journal of Business Management, 47(3), 25-34

Nam, J., Ekinci, Y., \& Whyatt, G. (2011). Brand equity, brand loyalty and consumer satisfaction. Annals of Tourism Research, 38(3), 1009-103. https://doi.org/10.1016/j.annals.2011.01.015

Ushakov, D.S., Yushkevych, O.O., Ovander, N.L., Tkachuk, H.Yu., \& Vyhovskyi, V.H. (2019). The strategy of thai medical services promotion at foreign markets and development of medical tourism. GeoJournal of Tourism and Geosites, 27(4), 1429-1438. https://doi.org/10.30892/gtg.27426-445

Tuzunkan D. (2018). Customer Relationship Management in Businessto-Business Marketing: Example of Tourism Sector. GeoJournal of Tourism and Geosites, 22(2), 329-338. https://doi.org/10.30892/gtg.22204-291

Ozturk, A.B., Bilgihan, A., Nusair, K., \& Okumus, F. (2016). What keeps the mobile hotel booking users loyal? Investigating the roles of self-efficacy, compatibility, perceived ease of use, and perceived convenience. International Journal of Information Management, 36, 1350-1359. https://doi.org/10.1016/j.ijinfomgt.2016.04.005

Plooy-Cilliers, F.D., Davis, C., \& Bezuidenhout, R.M. (2014). Research Matters. 1ed.Cape Town: Juta legal and Academic Publishers.

Schiffman, L.G., \& L. Wisenblit, J. (2015). Consumer Behaviour. 11 ed. London, Pearson Education.

Schumacker, R.E., \& Lomax, R.G. (2004). A beginner's guide to structural equation modeling. 2nd ed. New Jersey, Lawrence Erlbaum Associates, Inc.

Shafiee, M.M., \& Bazargan, N.A. (2018). Behavioral Customer Loyalty in Online Shopping: The Role of E-Service Quality and E-Recovery. Journal of Theoretical and Applied Electronic Commerce Research, 13(1), 26-38. https://doi.org/10.4067/S0718-18762018000100103

So, K.K.F., King, C., Hudson, S., \& Meng, F. (2017). The missing link in building customer brand identification: The role of brand attractiveness. Tourism Management, Volume 59, 640-651. https://doi.org/10.1016/j.tourman.2016.09.013

So, K.K.F., King, C., Sparks, B.A., \& Wang, Y. (2013). The influence of customer brand identification on hotel brand evaluation and loyalty development. International Journal of Hospitality Management, 34, 31-41. https://doi.org/10.1016/j.ijhm.2013.02.002

Stangl, B., Inversini, A., \& Schegg, R. (2016). Hotels' dependency on online intermediaries and their chosen distribution channel portfolios: Three country insights. International Journal of Hospitality Management, 52, 87-96. http://dx.doi.org/10.1016/j.ijhm.2015.09.015

Yang, Y., Lu, Q., Tang, G., \& Pei, J. (2015). The Impact of Market Competition on Search Advertising. Journal of Interactive Marketing, Volume 30, 46-55. https://doi.org/10.1016/j.intmar.2015.01.002

Yeh, H., Wang, Y.S., \& Yieh, K. (2016). Predicting smartphone brand loyalty: Consumer value and -brand identification perspectives. International Journal of Information Management, 36, 245-257.

Yoo, M., \& Baib, B. (2013). Customer loyalty marketing research: A comparative approach between hospitality and business journals. International Journal of Hospitality Management, Volume 33, 166-177. https://doi.org/10.1016/j.ijhm.2012.07.009

Yüksel, A., \& Yüksel, F. (2001). The Expectancy-Disconfirmation Paradigm: A Critique. Journal of Hospitality \& Tourism Research, 25(2), 107-131. https://doi.org/10.1177/109634800102500201

*** The University of Texas, (2012). Structural Equation Modeling Using AMOS, Austin, The University of Texas.

$\begin{array}{lll}\text { Article history: } & \text { Received: 29.10.2019 Revised: 04.05.2020 }\end{array}$
Accepted: 09.07.2020
Available online: 30.07 .2020 